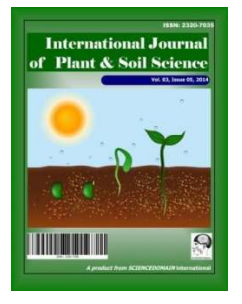

\title{
Impact of Biogas Slurry on Some Physical Properties in Sandy and Calcareous Soils, Egypt
}

\author{
Mohamed A. Bassouny ${ }^{1^{*}}$ and Ahmed S. Abuzaid ${ }^{1}$ \\ ${ }^{1}$ Department of Soil and Water, Faculty of Agriculture, Moshtohor, Benha University, Egypt.
}

Authors' contributions

This work was carried out in collaboration between both authors. Author MAB designed the study, performed the statistical analysis, wrote the protocol, managed the literature searches and wrote the first draft of the manuscript. Author ASA managed the sampling site selection, edited the data, reviewed and edited the protocol and manuscript. Both authors read and approved the final

manuscript.

\section{Article Information}

DOI: $10.9734 /$ IJPSS/2017/33388

Editor(s):

(1) Fatemeh Nejatzadeh, Department of Horticulture, Faculty of Agriculture, Khoy Branch, Islamic Azad University, Iran.

Reviewers:

(1) Raul Antonio Sperotto, Centro Universitário UNIVATES, Brazil.

(2) K. N. Swamy, Osmania University, Hyderabad, India.

(3) Gunnar Bengtsson, Lund University, Sweden.

(4) Abdulwahed Mohamed Aboukarima, Agricultural Engineering Research Institute, Egypt.

(5) Godwin Michael Ubi, University of Calabar, Calabar, Nigeria.

(6) Sillma Rampadarath, University of Mauritius, Mauritius.

Complete Peer review History: http://www.sciencedomain.org/review-history/19505

Original Research Article

Received 12 $2^{\text {th }}$ April 2017

Accepted $21^{\text {st }}$ May 2017

Published $13^{\text {th }}$ June 2017

\section{ABSTRACT}

Sandy and calcareous soils in Egypt are promising for increasing cultivated area to suffice the growing food demand; however, their physical properties adverse plant growth. Hence, the current work was carried out to evaluate the effect of biogas slurry (BGS) application rates of $0,30,60$ and $90 \mathrm{~g} \mathrm{~kg}^{-1}$ on physical properties in sandy and calcareous soils. Soils were incubated for six months under laboratory conditions keeping the moisture content around $70 \%$ of holding capacity. The BGS applications resulted in significant increases $(P<0.05)$ in organic matter content, total soil porosity, air-filled porosity and water holding capacities while decreased bulk density and void ratio in both soils compared to the control (untreated soils). Soil hydraulic conductivity significantly $(\mathrm{P}<$ 0.05 ) decreased in sandy soil but increased in calcareous soil, with the highest application rate of $90 \mathrm{~g} \mathrm{~kg}^{-1}$ being the most effective treatment. Generally, the BGS proved success in ameliorating soil physical properties. 
Keywords: Biogas slurry; porosity; bulk density; air-filled porosity; void ratio; hydraulic conductivity; soil moisture content.

\section{INTRODUCTION}

Declining the cultivated land in Nile Valley and Delta, Egypt has pushed the agricultural expansion into the wide desert to suffice the growing food demand [1]. Sandy and calcareous soils occupy the majority of the Egyptian desert lands; however, their use is limited by adverse physical properties [2]. Sandy soils have inherent low fertility and water-holding capacity [3], while high content of calcium carbonate affects negatively soil water relations and plant nutrition in calcareous soil [4]. Low organic matter content seems to be the key factor contribute such unsavory effects [5]. Thus, incorporation of organic fertilizers into the soils alleviate the negative effects and improve soil properties [6].

Under arid and semi-arid conditions, much attention has been drawn on the significance of supplementing organic materials to the soils to improve the physiochemical properties $[7,8]$. Organic fertilizers are the main available sources for increasing organic matter in the soil [9]. When organic solids are incorporated into the soil, a gradual assimilation occurs through chemical and biological reactions. Mineralization of nutrients releases many nutrients in the forms available for plants uptake. Organic matter amendments improve soil physical conditions [10], enhancing plant growth parameters and increase yield [11].

Soil physical properties such as bulk density, porosity, hydraulic conductivity and moisture content are important components of soil quality that affect availability and uptake of water, oxygen, and nutrients [12]. Soil bulk density is an index of the soil penetration resistance to root growth [13] and to characterize soil compaction [14]. Soil porosity expresses the amount of space available to a fluid within the body of the soil [15]. It is the fraction of the total soil volume that is taken up by the pore space [9]. By convention, the definition of pore space excludes fluid pockets that are totally enclosed within the soil solid material [16]. Porosity is mainly responsible for the exchange of gases and water in the soil. Void ratio is a characteristic of compact soil and is defined as a volumetric ratio of the volume of void-spaces to the volume of soil [17]. Soil airfilled porosity is important [16] for soil aeration and is commonly used to estimate the availability of oxygen to plant roots [18]. Hydraulic conductivity is important for soil water flow, surface water infiltration and runoff and sub-soil water recharge [19]. Soil moisture content is the primary factor that limits productivity among farming systems [20] and is a fundamental property affecting plant growth, transport, and transformation of soil nutrients [21].

Biogas slurry (BGS) raises agricultural productivity and enhances soil fertility. It is a product of the anaerobic digestion of organic materials. Such product includes methane gas along with traces of $\mathrm{H}_{2} \mathrm{~S}, \mathrm{CO}_{2}, \mathrm{NH}_{3}, \mathrm{H}_{2}, \mathrm{CO}$ besides BGS [22]. Organic materials obtained as a by-product from biogas slurry technology are used as organic fertilizers. The slurry produced by the biogas is effective as a soil conditioner [23]. Biogas contains many rich nutrients including nitrogen, phosphorous, potassium, iron and trace elements [24]. The anaerobic digestion of organic matter using biogas slurry technology produces materials that are utilized as crop nutrients which are free of weed seeds [25]. The effect of BGS on soil physical properties largely depends on the rate of decomposition and its contribution to soil organic content. Factors affecting the rate of decomposition include; chemical composition of the BGS, soil temperature, soil moisture, method of BGS application (surface-applied or soil-incorporated) and rate of application [26]. Soil applications of BGS at different rates were evaluated by previous studies in Egypt [27,28]. They indicated the effectiveness of BGS in improving soil physical properties and enhancing crop yield. BGS improves aggregation, water-holding capacity, pore size distribution, hydraulic conductivity and porosity $[29,30]$.

The objective of the current study is to evaluate the changes of soil physical properties; bulk and particle density, porosity, hydraulic conductivity, and water content in sandy and calcareous soils as affected by different application rates of biogas slurry to determine the possibility of using such material in improving the aforementioned properties of newly reclaimed soils.

\section{MATERIALS AND METHODS}

\subsection{Biogas Slurry (BGS)}

The BGS used for the current study was from anaerobic digestion of organic materials obtained from the training center for biogas and recycling 
of agricultural waste (TRRAR), Moshtohor, Qalubiya Governorate, Egypt. The biogas slurry was air-dried and passed through a 2-mm sieve before mixing with the soils. The main composition of the BGS is shown in Table 1.

Table 1. Main properties of biogas slurry (on dry weight basis) applied to the soil

\begin{tabular}{lll}
\hline Properties & Unit & Value \\
\hline pH $(1: 10$ BGS : water $)$ & $-\operatorname{log~}\left[\mathrm{H}^{+}\right]$ & 7.54 \\
EC (1:10 BGS : water) & $\mathrm{dS} \mathrm{m}^{-1}$ & 2.53 \\
Organic matter & $\mathrm{g} \mathrm{kg}^{-1}$ & 408.10 \\
Bulk density & $\mathrm{Mg} \mathrm{m}^{-3}$ & 0.387 \\
Moisture content & $\%$ & 23.64 \\
Total N & $\mathrm{g} \mathrm{kg}^{-1}$ & 8.20 \\
Total P & $\mathrm{g} \mathrm{kg}^{-1}$ & 9.50 \\
Total K & $\mathrm{g} \mathrm{kg}^{-1}$ & 16.30 \\
\hline
\end{tabular}

\subsection{Soils}

Two soils were tested; the first is sandy soil taken from Wadi El-Natrun region, the Western Desert of Egypt, classified as Typic Torripsamments, and the second is calcareous sandy loam soil taken from El-Nubaria region near Cairo-Alexandria desert road, classified as Typic Haplocalcids [31]. Soil samples were collected from the surface layer $(30 \mathrm{~cm})$. The soils were of low organic matter, low water retention and low fertility. The soils were airdried, passed through $2 \mathrm{~mm}$ sieve. Particle size distribution was determined by the pipette method, using sodium hexametaphosphate as a dispersing agent [32]. Organic matter was determined by using the modified Walkley and Black method [33]. The $\mathrm{pH}, \mathrm{EC}$, and $\mathrm{CaCO}_{3}$ were also estimated [34]. Main properties of the soils are given in Table 2.

\subsection{Experimental Design}

A laboratory experiment was performed using a completely randomized design with 5 replicates. There were eight (8) treatments as follows: 0, 30, 60 and $90 \mathrm{~g} \mathrm{~kg}^{-1}$ for sandy soil and 0,30,60 and $90 \mathrm{~g} \mathrm{~kg}^{-1}$ for calcareous soil (total number of treatments 40 experimental units). Three kilograms each of sandy and calcareous soils were thoroughly mixed with 0 (control), 90, 180 and $270 \mathrm{~g} \mathrm{BGS}$, and moisture was kept $70 \%$ of water holding capacity using distilled water. Soils were covered with polyethylene sheets and water content was maintained constant by weighing the pot weekly and bringing it to its initial weight by adding distilled water. The prevailing ambient room temperature during incubation period ranged from 24 to $30^{\circ} \mathrm{C}$.

\subsection{Soil Measurements and Data Analysis}

After six months of incubation, the following determinations were carried out on the treated soil: soil bulk density (BD) was determined on undisturbed soil samples using a steel cylinder of $100 \mathrm{~cm}^{3}$ volume. On the other hand, the particle size density (PD) was measured by a pycnometer. From both $\mathrm{BD}$ and $\mathrm{PD}$ the total porosity (TP), the void ratio (VR) and air-filled porosity (AFP) were calculated as follows [35]:

$$
\begin{aligned}
& T P=\frac{P D-B D}{P D} \times 100 \\
& V R=\frac{T P}{(1-T P)} \\
& A F P=T P-S
\end{aligned}
$$

Where $S$ is saturation degree

Soil cores were sampled by a cylinder to measure the saturated hydraulic conductivity in the laboratory using the constant-head method. Water holding capacity at 0.33 bar (field water capacity) and at15 bar (wilting point) were determined in undisturbed samples. Available water capacity (AWC) was then determined considering the difference between water retained at 0.33 and 15 bars [36]. Data were all analyzed using analysis of variance at a 0.05 level, using SPSS19.0 for Windows (SPSS Inc., Chicago, USA). A correlation matrix of different properties was based on linear correlation coefficients $(p<0.05$ and $p<0.01)$.

\section{RESULTS AND DISCUSSION}

\subsection{Soil Organic Matter, Bulk Density and Particle Size Density}

Results in Table 3 show the effect of different application rates of BGS on soil organic matter (SOM), bulk density (BD) and particle size density (PD) in sandy soil and calcareous soil. Treating the soils with BGS resulted in a significant increase in SOM $(P<0.05)$ with slight differences among the applied rates. Insignificant differences were identified in both soils between the applied rates of 60 and $90 \mathrm{~g} \mathrm{~kg}^{-1}$, which increased SOM by $26 \%$ and $33 \%$ for the sandy soil respectively, and $9.23 \%$ and $13.07 \%$ for the calcareous soil respectively compared to the control. On the other hand, the lowest application rates of $30 \mathrm{~g} \mathrm{BGS} \mathrm{kg}^{-1}$ had an insignificant effect. This result is in agreement with $[37,38]$ who reported that applications of BGS increased soil organic matter. Generally, organic fertilizers 
enhance organic carbon storage in soil and improve soil fertility $[39,40]$

The bulk density (BD) of the sandy and calcareous soils significantly $(P<0.05)$ decreased with the BGS applications with slight differences among the applied rates. The application rates of 30,60 and $90 \mathrm{~g} \mathrm{~kg}^{-1}$ decreased soil BD at the sandy soil by $4.17,8.92$ and $11.90 \%$, respectively compared to the control. Treating the calcareous soil with the same rates resulted in decreases by $5.03,10.07$ and $13.67 \%$ respectively compared to the control.

The highest application rate of $90 \mathrm{~g} \mathrm{~kg}^{-1}$ resulted in significant decrease in soil particle density (PD) by $0.10 \mathrm{Mg} \mathrm{m}^{-3}$ in both soils compared to the control. Also, the application rate of $60 \mathrm{~g} \mathrm{~kg}^{-1}$ decreased PD significantly by $0.05 \mathrm{Mg} \mathrm{m}^{-3}$ in both soils compared to the control; however, soils received $30 \mathrm{~g} \mathrm{~kg}^{-1}$ showed an insignificant decrease. Soil density is inversely related to the changes in soil organic matter [41], thus significant decreases in soil BD and PD have been reported in different soils upon application of BGS at different rates [42-44]. Organic materials have low density, thus mixing these less dense materials with denser mineral fractions of soils induce a dilution effect, decreasing both bulk and particle density [45].

\subsection{Soil Total Porosity, Air-Filled Porosity and Void Ratio}

Results in Table 4 illustrate the effect of BGS at different rates on soil total porosity (TP), air-filled porosity (AFP) and void ratio (VR) in soils. The BGS application resulted in a significant increase $(P<0.05)$ in TP for both soils with slight differences among application rates. The application rates of 60 and $90 \mathrm{~g} \mathrm{~kg}^{-1}$ had the same effect in the two soils and induced significant increase by 13.05 and $15.32 \%$, respectively in sandy soil and 9.36 and $11.50 \%$ in calcareous soil compared to the control. On the other hand, the application of $30 \mathrm{~g} \mathrm{~kg}^{-1}$ had an insignificant effect in the two soils. The BGS increased AFP with slight differences among application rates.

The increases in sandy soils were 1.53, 2.11 and 2.29 folds for soils treated with 30,60 and $90 \mathrm{~g}$ $\mathrm{kg}^{-1}$, respectively; while in the calcareous soil, the corresponding increases were 1.54, 2.15 and 2.41 folds, respectively for the same rates. The VR decreased in sandy soil in response to BGS applications; however, the decreases were slight. On the other hand, the applied BGS rates did not significantly affect VR in calcareous soil. These results are in agreement with $[43,46]$ who found that application of BGS improved soil aeration by increasing total porosity and air-

Table 2. Physiochemical properties of the studied soils

\begin{tabular}{|c|c|c|c|c|c|c|c|c|c|}
\hline \multirow[t]{2}{*}{ Soils } & \multirow[t]{2}{*}{$\mathrm{pH}^{*}$} & \multirow{2}{*}{$\begin{array}{l}E^{\star * *} \\
d^{-1} m^{-1}\end{array}$} & \multirow{2}{*}{$\begin{array}{l}\text { OM } \\
\mathrm{g} \mathrm{kg}^{-1}\end{array}$} & \multirow{2}{*}{$\begin{array}{l}\mathrm{CaCO}_{3} \\
\mathrm{~g} \mathrm{~kg}^{-1}\end{array}$} & \multirow{2}{*}{$\begin{array}{l}\text { Texture } \\
\text { (USDA) }\end{array}$} & \multicolumn{4}{|c|}{ Particle size distribution, $\%$} \\
\hline & & & & & & $\begin{array}{l}\text { Fine } \\
\text { sand }\end{array}$ & $\begin{array}{l}\text { Coarse } \\
\text { sand }\end{array}$ & Silt & Clay \\
\hline Sandy soil & 8.14 & 2.18 & 2.20 & 22.30 & Sand & 38.0 & 55.5 & 2.5 & 4.0 \\
\hline Calcareous soil & 8.09 & 1.25 & 4.50 & 221.10 & Sandy loam & 36.1 & 37.1 & 8.0 & 18.8 \\
\hline
\end{tabular}

Table 3. Effect of BGS applications on soil organic matter (SOM), bulk density (BD) and particle size density (PD) under sandy soil and calcareous soil

\begin{tabular}{|c|c|c|c|c|}
\hline Soils & BGS $\left(\mathrm{g} \mathrm{kg}^{-1}\right)$ & $\operatorname{SOM}\left(\mathrm{g} \mathrm{kg}^{-1}\right)$ & $\mathrm{BD}\left(\mathrm{Mg} \mathrm{m}^{-3}\right)$ & $\mathrm{PD}\left(\mathrm{Mg} \mathrm{m}^{-3}\right)$ \\
\hline \multirow[t]{5}{*}{ Sandy soil } & 0 & $2.20 \mathrm{~b}$ & $1.68 \mathrm{a}$ & $2.60 \mathrm{a}$ \\
\hline & 30 & $2.51 \mathrm{ab}$ & $1.61 \mathrm{~b}$ & $2.58 \mathrm{ab}$ \\
\hline & 60 & $2.99 a$ & $1.53 \mathrm{bc}$ & $2.55 b$ \\
\hline & 90 & $3.30 a$ & $1.48 \mathrm{c}$ & $2.50 \mathrm{c}$ \\
\hline & Mean & 2.75 & 1.57 & 2.55 \\
\hline \multirow{5}{*}{ Calcareous soil } & 0 & $4.50 \mathrm{~b}$ & $1.39 a$ & $2.63 a$ \\
\hline & 30 & $4.75 a b$ & $1.32 b$ & $2.60 \mathrm{ab}$ \\
\hline & 60 & $4.98 a$ & $1.25 \mathrm{bc}$ & $2.58 b$ \\
\hline & 90 & $5.20 a$ & $1.20 c$ & $2.53 c$ \\
\hline & Mean & 4.86 & 1.29 & 2.58 \\
\hline
\end{tabular}

Note: Values followed by the same letter within a column indicate no significant difference at 0.05 level 
Table 4. Effect of BGS on soil total porosity (TP), air-filled porosity (AFP) and void ratio (VR) in sandy soil and calcareous soil

\begin{tabular}{lllll}
\hline Soils & BGS $\left(\mathbf{g ~ k g}^{-1}\right)$ & TP $(\%)$ & AFP $(\%)$ & VR \\
\hline Sandy soil & 0 & $35.38 \mathrm{~b}$ & $4.18 \mathrm{c}$ & $1.029 \mathrm{a}$ \\
& 30 & $37.59 \mathrm{ab}$ & $6.39 \mathrm{~b}$ & $1.027 \mathrm{ab}$ \\
& 60 & $40.00 \mathrm{a}$ & $8.80 \mathrm{ab}$ & $1.025 \mathrm{~b}$ \\
& 90 & $40.80 \mathrm{a}$ & $9.60 \mathrm{a}$ & $1.025 \mathrm{~b}$ \\
& Mean & 38.44 & 7.24 & 1.026 \\
\hline Calcareous soil & 0 & $47.14 \mathrm{~b}$ & $3.84 \mathrm{c}$ & $1.021 \mathrm{a}$ \\
& 30 & $49.23 \mathrm{ab}$ & $5.93 \mathrm{~b}$ & $1.020 \mathrm{a}$ \\
& 60 & $51.55 \mathrm{a}$ & $8.25 \mathrm{ab}$ & $1.019 \mathrm{ab}$ \\
& 90 & $52.56 \mathrm{a}$ & $9.26 \mathrm{a}$ & $1.019 \mathrm{ab}$ \\
& Mean & 50.12 & 6.82 & 1.019 \\
\hline
\end{tabular}

Note: Values followed by the same letter within a column indicate no significant difference at 0.05 leve

filled porosity, and decreased void ratio. The observed changes go beyond the fact that application of BGS improved soil structure by better aggregation of individual soil particles and decreased BD $[47,48]$.

\subsection{Soil Saturated Hydraulic Conductivity}

The BGS applications resulted in significant decrease $(P<0.05)$ in saturated hydraulic conductivity $(K s)$ in sandy soils (Fig. 1). The greatest reduction related to the highest application rate of $90 \mathrm{~g} \mathrm{~kg}^{-1}$, which caused a $34.91 \%$ decrease compared to the control. The application rate of $60 \mathrm{~g} \mathrm{~kg}^{-1}$ caused a decrease of $25.90 \%$, while soil amended with $30 \mathrm{~g} \mathrm{~kg}^{-1}$ showed an insignificant decrease. On the other hand, the applied BDS rates increased Ks in calcareous soil and the highest increase associated with the highest application rate of 90 $\mathrm{g} \mathrm{kg}^{-1}$. The increases were 2.56 and 1.93 folds for soils amended with 90 and $60 \mathrm{~g} \mathrm{~kg}^{-1}$, respectively; however, the application rate $30 \mathrm{~g}$ $\mathrm{kg}^{-1}$ had no significant effect.

Changes in soil hydraulic conductivity in response to the organic matter application have been reported [49-51]. The observed Ks decrease in sandy soil based on the dispersion and expansion of soil colloid particle enhanced by BGS applications, and thus blocking macropores. Moreover, BGS can adsorb and fix various inorganic ions as well as polar or nonpolar organic compounds, thereby forming stable aggregates in the sandy soil, thus possibly filled pore spaces, which means a reduction in soil hydraulic conductivity [43,52]. On the other hand, Ks increase in calcareous soil is a result of improving soil structure due to decreased bulk density and increased porosity. These positive changes enhanced the resistance to soil compaction results from the cementing agent; calcium carbonate and led finally to increase soil hydraulic conductivity $[50,53,54]$.

\subsection{Soil Moisture Characteristics}

Data illustrated in Figs. 2, 3 and 4 show that treating the two soils with the BGS had significant effects $(P<0.05)$ on moisture constants with slight differences among application rates. The field water capacity (FWC) in sandy soil increased by $43.17,60.77$ and $86.63 \%$ for soils amended with 30,60 and $90 \mathrm{~g}$ $\mathrm{kg}^{-1}$, respectively (Fig. 2). With the calcareous soil, the application rate of $30 \mathrm{~g} \mathrm{~kg}^{-1}$ had no significant effect $(P<0.05)$ on FWC, while no significant differences were observed between the application rates of 60 and $90 \mathrm{~g} \mathrm{~kg}^{-1}$, and caused 9.21 and $14.05 \%$, respectively increases compared to the control. Likewise, the wilting point (WP) increased in sandy soil by 1.85, 2.01 and 2.20 folds in response to application rates of 30,60 and $90 \mathrm{~g} \mathrm{~kg}^{-1}$, respectively (Fig. 3). Contradictory, the WP in calcareous soil did not show the same trend, since the application rates of 60 and $90 \mathrm{~g} \mathrm{~kg}^{-1}$ decreased WP by 21.07 and $27.08 \%$, respectively; however, the application rate of $30 \mathrm{~g} \mathrm{~kg}^{-1}$ showed insignificant effect. The BGS application rates of 30,60 and $90 \mathrm{~g} \mathrm{~kg}^{-1}$ increased available water content (AWC) by $32.34,50.43$ and $77.94 \%$, respectively in sandy soils and $11.47,25.21$ and $35.77 \%$, respectively in calcareous soil. Several researchers $[18,19,55]$ reported improved water holding capacity at field water capacity and wilting point, with the application of the organic material. It is well known that water holding capacity is an important soil property that is directly related to soil porosity; micro and macro pores [56]. Water capacity of soils with high micro-pores was reported to be higher than the soils with low 
micro-pores [57]. This can give an interpretation for increased water holding capacity with the BGS applications due to increasing small pores while decreasing large pores [58]. The humic substances and other organic compounds such as polysaccharides and bacterial gums augment the binding force between particles, enhancing formation of soil aggregates. Moreover, organic materials have usually a large surface area that enables adsorbing more water [59].

The different effects resulted from the BGS on water content in the two soils could be due to one or more of the followings: a) The BGS particles can retain more water due to their large surface area which adheres water films; b) The BGS particles may fill the pore space between soil particles, thus reducing its volume, which results in pores with smaller radius holding more moisture at relatively highly amount [16]. The effect of BGS application on the calcareous soil was influenced by its high $\mathrm{CaCO}_{3}$ content as well as its heavier texture in comparison with the sandy soil [29]. Islam et al. [60] found that addition of BGS to sandy and highly calcareous soils improved their physical properties.

\subsection{Correlation among Soil Properties}

As shown in Table 5, the BD showed a negative correlation with Soil OM in both soils, which indicates that organic matter, caused a decrease in $\mathrm{BD}$. Also, there was a negative correlation between the VR and SOM, indicating that the VR decreased with increased organic matter content; indicating that decreases in BD and VR improved the soil structure. The VR showed a negative correlation with the AWC, and this AWC showed a significant negative correlation with the $K s$ in calcareous soil. The high negative correlations observed between the SOM and the BD and the VR are due to the increase in the labile fraction of the organic carbon released through the microbial decomposition of organic matter and deposited on the soil as a surface coating, causing aggregation [61]. The Ks showed a negative correlation with the SOM and a positive correlation with $B D$ and VR in the sandy soil, therefore improving water holding capacity. In calcareous soil, the $K s$ showed a significant negative correlation with the $\mathrm{BD}$ and $\mathrm{VR}$, and a positive correlation with SOM, therefore, improving hydraulic properties.

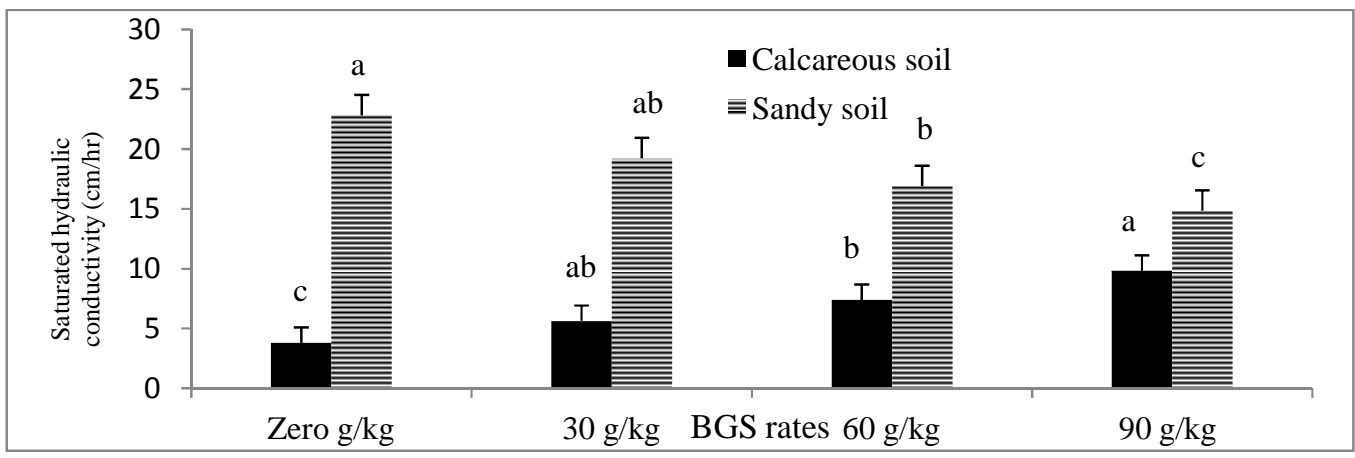

Fig. 1. Effect on BGS applications on saturated hydraulic conductivity $(K s)$ under sandy and calcareous soils. Vertical bars indicate mean \pm 1 standard error

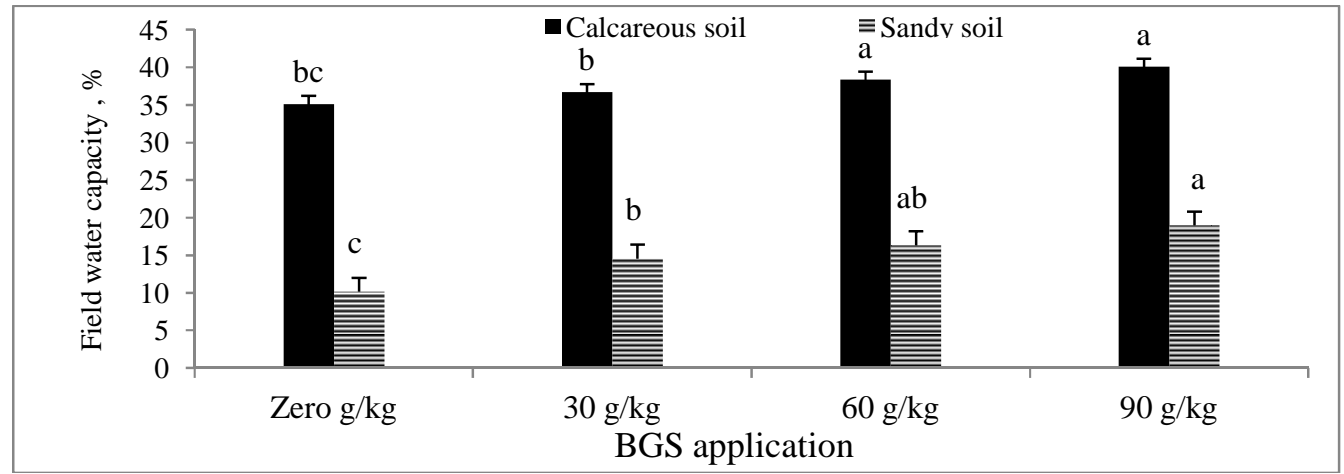

Fig. 2. Effect on BGS applications on field water capacity (FWC) under sandy and calcareous soils. Vertical bars indicate mean \pm 1 standard error 


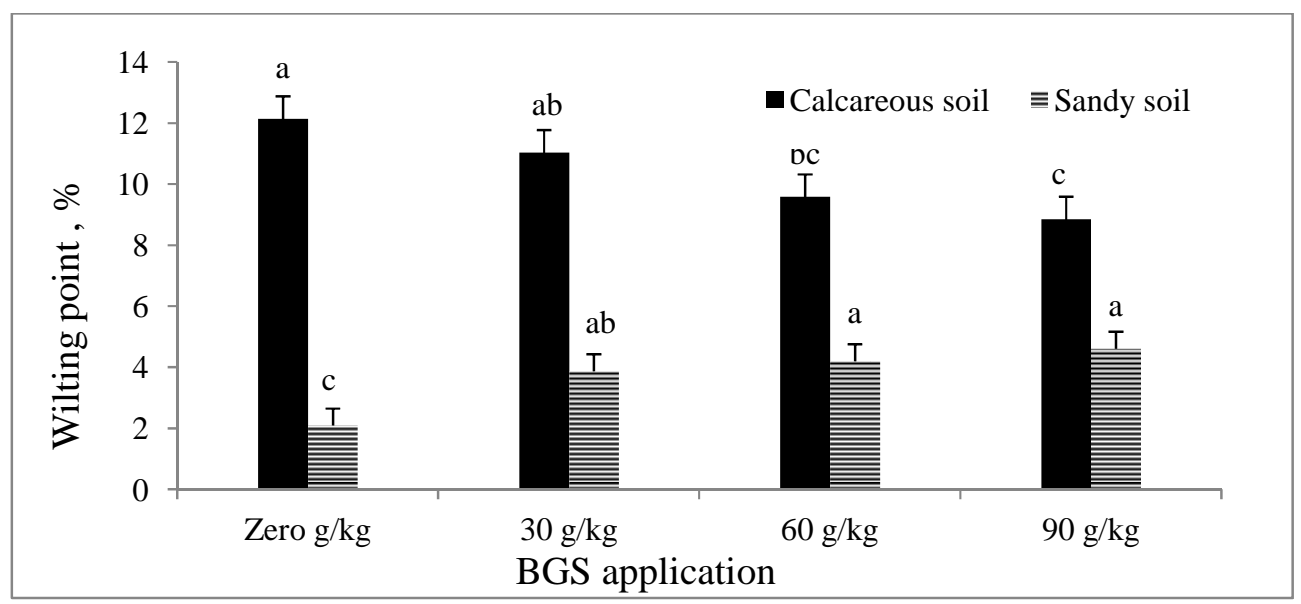

Fig. 3. Effect on BGS applications on wilting point (WP) under sandy and calcareous soils. Vertical bars indicate mean \pm 1 standard error

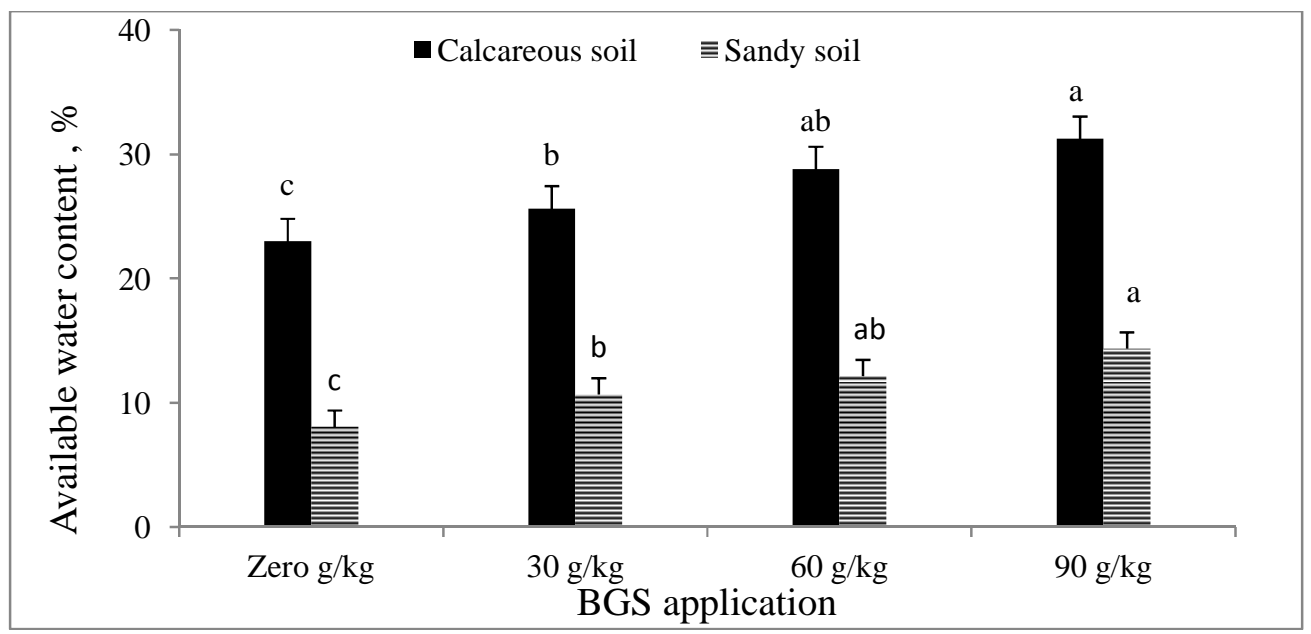

Fig. 4. Effect on BGS applications on available water content (AWC) under sandy and calcareous soils. Vertical bars indicate mean \pm 1 standard error

Table 5. Correlation coefficients among soil organic matter (SOM), bulk density (BD), void ratio (VR), saturated hydraulic conductivity (Ks) and available water content (AWC) in sandy and calcareous soils

\begin{tabular}{|c|c|c|c|c|}
\hline \multicolumn{5}{|c|}{ Sandy soil } \\
\hline & BD & VR & $K s$ & AWC \\
\hline SOM & $-0.95^{\star *}$ & $-0.70^{\star}$ & $-0.85^{\star *}$ & $0.94^{\star \star}$ \\
\hline $\mathrm{BD}$ & & $0.71^{*}$ & $0.84^{\star *}$ & $-0.87^{\star *}$ \\
\hline VR & & & $0.81^{* *}$ & $-0.73^{*}$ \\
\hline Ks & & & & $-0.88^{* *}$ \\
\hline \multicolumn{5}{|c|}{ Calcareous soil } \\
\hline SOM & $-0.94^{* *}$ & $-0.66^{*}$ & $0.88^{* *}$ & $0.89^{* *}$ \\
\hline BD & & $0.62^{*}$ & $-0.85^{\star *}$ & $-0.88^{* *}$ \\
\hline VR & & & $-0.67^{\star}$ & $-0.68^{*}$ \\
\hline Ks & & & & $0.87^{* *}$ \\
\hline
\end{tabular}




\section{CONCLUSIONS}

The BGS can serve as valuable organic input for improving adverse physical properties in sandy and calcareous soils. The BGS application increased soil organic matter and decreased soil bulk and particle size density. The increases accompanied with BGS application in soil total porosity and air-filled porosity, and the decrease in void ratio, improved soil aeration, especially in calcareous soil. The BGS improved water holding capacity by increasing field water capacity and available water content in both soils. The highest BGS application rate of $90 \mathrm{~g}$ $\mathrm{kg}^{-1}$ caused positive changes in hydraulic conductivity for the two soils, as it caused a decrease in sandy soil and an increase in cemented calcareous soil. Finally, the BGS can be used intensively in the reclamation of sandy and calcareous soil covering large wide areas in Egyptian deserts.

\section{ACKNOWLEDGEMENTS}

The authors express their deep thanks to Prof. Dr. Ali Abdel Salam, Soil and Water Department, Faculty of Agriculture, Moshtohor, Benha University, Egypt for his valuable comments and help during the study.

\section{COMPETING INTERESTS}

Authors have declared that no competing interests exist.

\section{REFERENCES}

1. Arnous $\mathrm{MO}$, El-Rayes AE, Helmy AM. Land-use/land-cover change: $A$ key to understanding land degradation and relating environmental impacts in Northwestern Sinai, Egypt. Environ Earth Sci. 2017;76(7):263.

2. Sudnitsyn I. Promising method of sandy soil reclamation. Eurasian Soil Sci. 2011;44(9):1039-1040.

3. Tahir S, Marschner P. Clay amendment to sandy soil: Effect of clay concentration and ped size on nutrient dynamics after residue addition. J Soils Sediments. 2016;16(8): 2072-2080.

4. Aboukila EF, Nassar IN, Rashad M, Hafez $\mathrm{M}$, Norton JB. Reclamation of calcareous soil and improvement of squash growth using brewers' spent grain and compost. J Saudi Soc Agric Sci; 2016. (In press)
5. Llorente M, Glaser B, Turrion MB. Effect of land use change on contents and distribution of monosacharides within density fractions of calcareous soil. Soil Biol Biochem. 2017;107:260-268.

6. Moharana PC, Sharma BM, Biswas DR. Changes in the soil properties and availability of micronutrients after six-year application of organic and chemical fertilizers using STCR-based targeted yield equations under pearl millet-wheat cropping system. J Plant Nutr. 2017;40(2):165-176.

7. Ghimire R, Norton U, Bista P, Obour AK, Norton JB. Soil organic matter, greenhouse gases and net global warming potential of irrigated conventional, reduced-tillage and organic cropping systems. Nutr Cycl Agroecosyst. 2017;107(1):49-62.

8. Diacono M, Montemurro F. Effectiveness of organic wastes as fertilizers and amendments in salt-affected soils. Agriculture-Basel. 2015;5(2):221-230.

9. El-Samanoudy M, Askar F, El- Shakweer M. Reclamation of calcareous soil and improvement of squash growth using brewers' spent grain and compost. Egypt J Soil Sci. 1993;33(3):35-45.

10. Abdel-Sabour M, Ogden C, El- Gendi R. Conditioning effect of organic waste composts on hydro-physical properties of Inshas sandy soils. Egypt J Soil Sci. 1997;37(2):355-366.

11. Moreira $\mathrm{WH}$, et al. Seasonal changes in soil physical properties under long-term no-tillage. Soil Tillage Res. 2016;160:5364.

12. Xin $\mathrm{XL}$, Zhang JB, Zhu AN, Zhang CZ. Effects of long-term (23 years) mineral fertilizer and compost application on physical properties of fluvo-aquic soil in the North China Plain. Soil Tillage Res. 2016;156:166-172.

13. Reynolds W, et al. Land management effects on the near-surface physical quality of a clay loam soil. Soil Tillage Res. 2007;96(1):316-330.

14. Celik I, Gunal H, Budak M, Akpinar C. Effects of long-term organic and mineral fertilizers on bulk density and penetration resistance in semi-arid Mediterranean soil conditions. Geoderma. 2010;160(2):236243. 
15. Guedes O, Blanco-Canqui $\mathrm{H}$, da Silva AP. Least limiting water range of the soil seedbed for long-term tillage and cropping systems in the central Great Plains, USA. Geoderma. 2013;207:99-110.

16. Nimmo J. Porosity and pore size distribution. Encyclopedia of Soils in the Environment. 2004;3:295-303.

17. Kirkham MB. Principles of soil and plant water relations. Academic Press; 2014.

18. Wall A, Heiskanen J. Soil-water content and air-filled porosity affect height growth of Scots pine in afforested arable land in Finland. For Ecol Manag. 2009;257(8): 1751-1756.

19. Zeng C, Wang Q, Zhang F, Zhang J. Temporal changes in soil hydraulic conductivity with different soil types and irrigation methods. Geoderma. 2013;193: 290-299.

20. Lin L, Chen J. The effect of conservation practices in sloped croplands on soil hydraulic properties and root-zone moisture dynamics. Hydrol Process. 2015;29(9):2079-2088.

21. Kahlon MS, Lal R, Ann-Varughese $M$. Twenty two years of tillage and mulching impacts on soil physical characteristics and carbon sequestration in central Ohio. Soil Tillage Res. 2013;126:151-158.

22. Abdul N, Khan F, Mahmood R, Khan M. Comparitive study of biogas slurry with farmyard manure as fertilizer on maize crop. Sci Int. (Lahore). 2010;22(4):297301.

23. Mahdi SS, et al. Bio-fertilizers in organic agriculture. J Phyt. 2010;2(10):42-54.

24. Garg RN, Pathak H, Das D, Tomar R. Use of flyash and biogas slurry for improving wheat yield and physical properties of soil. Environ Monit Assess. 2005;107(1):1-9.

25. Guedes Filho $O$, Blanco-Canqui $H$, da Silva A. Least limiting water range of the soil seedbed for long-term tillage and cropping systems in the central Great Plains, USA. Geoderma. 2013;207:99-110.

26. Tejada M, Gonzalez J. Crushed cotton gin compost on soil biological properties and rice yield. Eur J Agron. 2006;25(1):22-29.

27. Abdeladl M, Fouda S, Abou-Bakr N. Bean yield and soil parameters as response to application of biogas residues and ammonium nitrate under different water requirements. Egypt J Soil Sci; 2016. (In prees)

28. Shahein M, Afifi M, Algharib A. Assessing the effect of humic substances extracted from compost and biogas manure on yield and quality of lettuce (Lactuca sativa L.). American-Eurasian J Agric Environ Sci. 2014;4(10):996-1009.

29. Bin Z, Xin-Hua P. Organic matter enrichment and aggregate stabilization in a severely degraded ultisol after reforestation 11 project supported by the National Natural Science Foundation of China (No. 40071055). Pedosphere. 2006;16(6):699-706.

30. Yang X, Li P, Zhang S, Sun B, Xinping C. Long-term-fertilization effects on soil organic carbon, physical properties, and wheat yield of a loess soil. J Plant Nutr. Soil Sci. 2011;174(5):775-784.

31. Soil Survey Staff. Keys to soil taxonomy, $12^{\text {th }}$ edition. Washington, D.C, USA; 2014.

32. Kroetsch D, Wang C. Particle size distribution. In: Carter MR, Gregorich EG, editors. Soil sampling and methods of analysis. $2^{\text {nd }}$ edition. Taylor \& Francis Group, LLC: USA; 2007.

33. Nelson DW, Sommers LE. Total carbon, organic carbon, and organic matter. In: Sparks DL, editor. Methods of soil analysis. Part 3. Soil Science Society of America: Madison, Wisconsin, USA; 1996.

34. Sparks DL. Methods of soil analysis. Part 3. Madison, Wisconsin, USA: Soil Science Society of America; 1996.

35. Nimmo JR, Perkins KS. Aggregate stability and size distribution. In: Dane JH, Topp GC, editors. Methods of Soil Analysis Part 4. Physical Methods. Soil Science Society of America: Madison, Wisconsin, USA; 2002.

36. Klute A. Methods of soil analysis: Part 1physical and mineralogical methods. Madison, Wisconsin: Soil Science Society of America; 1986.

37. Eickenscheidt T, Freibauer A, Heinichen J, Augustin J, Drosler M. Short-term effects of biogas digestate and cattle slurry application on greenhouse gas emissions affected by $\mathrm{N}$ availability from grasslands on drained fen peatlands and associated organic soils. Biogeosciences. 2014; 11(22):6187-6207. 
38. Zheng XB, Fan JB, Xu L, Zhou J. Effects of combined application of biogas slurry and chemical fertilizer on soil aggregation and $\mathrm{C} / \mathrm{N}$ distribution in an Ultisol. Plos One. 2017;12(1):e0170491.

39. Moinet GYK, et al. Addition of nitrogen fertiliser increases net ecosystem carbon dioxide uptake and the loss of soil organic carbon in grassland growing in mesocosms. Geoderma. 2016;266:75-83.

40. Zheng $X$, et al. Effects of biogas slurry application on peanut yield, soil nutrients, carbon storage, and microbial activity in an Ultisol soil in southern China. J Soils Sediments. 2016;16(2):449-460.

41. Naveed $M$, et al. Impact of long-term fertilization practice on soil structure evolution. Geoderma. 2014;217:181-189.

42. Garg RN, Pathak H, Das DK, Tomar RK. Use of flyash and biogas slurry for improving wheat yield and physical properties of soil. Environ Monit Assess. 2005;107(1-3):1-9.

43. Du ZJ, et al. The effects of biochar and hoggery biogas slurry on fluvo-aquic soil physical and hydraulic properties: A field study of four consecutive wheat-maize rotations. J Soils Sediments. 2016;16(8):2050-2058.

44. Sun, Y., Ding, N., and Xing, Y.S. Key techniques and parameters for briquetting corn stover sprayed with biogas slurry in a cold region in China. Energ. Source. Part A. 2016; 38(9):1219-1235.

45. Parmar DK, Thakur DR, Jamwal RS Arpana. Effect of long term organic manure application on soil properties, carbon sequestration, soil - plant carbon stock and productivity under two vegetable production systems in Himachal Pradesh. J Environ Biol. 2016;37(3):333-339.

46. Yu WW, Zhang Z, Luo SR, Chen SL. Study on the characteristics of soil irrigated by biogas slurry in the Southwest of China. Asian J Chem. 2013;25(5):28612865.

47. Chaudhary S, Dheri GS, Brar BS. Longterm effects of NPK fertilizers and organic manures on carbon stabilization and management index under rice-wheat cropping system. Soil Tillage Res. 2017;166:59-66.

48. Zheng X, Fan J, Xu L, Zhou J. Effects of combined application of biogas slurry and chemical fertilizer on soil aggregation and
$\mathrm{C} / \mathrm{N}$ distribution in an Ultisol. PloS One. 2017;12(1):e0170491.

49. Shi YG, Zhao XN Gao, XD Zhang SL, Wu PT. The effects of long-term fertiliser applications on soil organic carbon and Hydraulic properties of a loess soil in China. Land Degrad Dev. 2016;27(1):6067.

50. Ibrahim A, et al. Effects of conocarpus biochar on hydraulic properties of calcareous sandy soil: Influence of particle size and application depth. Arch Agron Soil Sci. 2017;63(2):185-197.

51. Laghari $M$, et al. Effects of biochar application rate on sandy desert soil properties and sorghum growth. CATENA. 2015;135:313-320.

52. Bassouny M, Chen JZ. Effect of long-term organic and mineral fertilizer on physical properties in root zone of a clayey Ultisol. Arch Agron Soil Sci. 2016;62(6):819828.

53. Crawford JW, et al. Microbial diversity affects self-organization of the soilmicrobe system with consequences for function. $J$ Royal Soc. Interface. 2012;9(71):1302-10.

DOI: 10.1098/rsif.2011.0679

Epub 2011 Dec 7.

54. Tahir $\mathrm{M}$, et al. Effect of dairy manure and rice planting methods on Yield, soil quality, water-use efficiency, and economics of rice and succeeding wheat crop. Commun Soil Sci Plant Anal. 2012;43(14):18971914.

55. Shirani $H$, Hajabbasi M, Afyuni M, Hemmat A. Effects of farmyard manure and tillage systems on soil physical properties and corn yield in central Iran. Soil Tillage Res. 2002; 68(2):101-108.

56. Castellini M, Giglio L, Niedda M, Palumbo A, Ventrella D. Impact of biochar addition on the physical and hydraulic properties of a clay soil. Soil Tillage Res. 2015;154:113.

57. Aggelides S, Londra P. Effects of compost produced from town wastes and sewage sludge on the physical properties of a loamy and a clay soil. Bioresour Technol. 2000;71(3):253-259.

58. Mujdeci $M$, et al. Cooperative effects of field traffic and organic matter treatments on some compaction-related soil properties. Solid Earth. 2017;8(1):189-198. 
59. Xin X, Zhang J, Zhu A, Zhang C. Effects of long-term (23 years) mineral fertilizer and compost application on physical properties of fluvo-aquic soil in the North China Plain. Soil Tillage Res. 2016;156:166-172.

60. Islam M, Hossain N, Alamgir M, Kibria M. Comparative effects of biogas plant residues, poultry manure and inorganic fertilizer on growth and yield of ladies finger. IOSR J AgricVet Sci. 2014;7:29-33.

61. Herencia JF, Garcia-Galavis P, Maqueda C. Long-term effect of organic and mineral fertilization on soil physical properties under greenhouse and outdoor management practices. Pedosphere. $2011 ; 21(4): 443-453$.

(c) 2017 Bassouny and Abuzaid.; This is an Open Access article distributed under the terms of the Creative Commons Attribution License (http://creativecommons.org/licenses/by/4.0), which permits unrestricted use, distribution, and reproduction in any medium, provided the original work is properly cited.

Peer-review history:

The peer review history for this paper can be accessed here: http://sciencedomain.org/review-history/19505 